\title{
Quantification of common carp (Cyprinus carpio) IGF-I and IGF-II mRNA by real-time PCR: differential regulation of expression by $G H$
}

\author{
Q P Vong, K M Chan and C H K Cheng \\ Department of Biochemistry, The Chinese University of Hong Kong, Shatin, New Territories, Hong Kong, China \\ (Requests for offprints should be addressed to C H K Cheng; Email: chkcheng@cuhk.edu.hk)
}

\begin{abstract}
IGFs are potent mitogens for many different cell types and play important roles in growth and development. A multitude of regulatory factors modulate the expression of IGFs. In some teleosts, liver IGF-I expression has been demonstrated to depend on the presence of GH. However, the GH dependence of IGF-II expression in teleosts is controversial. Moreover, most IGF expression studies in bony fish have been focused on the liver, and information on extrahepatic tissues are conflicting and inconsistent. This is partly due to the fact that the traditional methods of mRNA measurement such as Northern blot and RT-PCR are not sensitive enough to detect changes in IGF levels in extrahepatic tissues because of the low levels of IGFs in these tissues. In addition, there have been few studies on the IGF system of non-salmonid teleosts. Our laboratory has thus begun such studies on a local tropical
\end{abstract}

fast-growing fish, the common carp (Cyprinus carpio). In this study, real-time quantitative PCR assays were developed for the accurate measurement of IGF-I and IGF-II mRNA levels in common carp tissues. This quantitative method was based on the measurement of a fluorescent labeled probe, which was cleaved by Taq polymerase during PCR by the $5^{\prime} \rightarrow 3^{\prime}$ nuclease activity. The signal generated was directly proportional to the starting copy number of the target molecules in the sample. Hence, it was possible to detect and quantify the mRNA levels of both IGF-I and IGF-II reliably in very small amounts of tissues obtained from juvenile common carp. Using these assays, the expression pattern of IGF-I and IGF-II in various common carp tissues was studied, and their differential response to $\mathrm{GH}$ stimulation was also investigated.

Journal of Endocrinology (2003) 178, 513-521

\section{Introduction}

Insulin-like growth factors (IGFs) are potent mitogens for many different cell types and play a central role in the growth, development and metabolism of vertebrates (Daughaday \& Rotwein 1989, de Pablo et al. 1990, Lowe 1991). These processes involve mitogenic stimulation and cell division, thus they need to be controlled accurately, particularly in response to the stimulation of different hormonal milieus.

In mammals, IGF-I is synthesized predominantly in the liver and is an important mediator of the action of growth hormone (GH) during postnatal life (Froesch et al. 1985). On the other hand, IGF-II shows little dependence on $\mathrm{GH}$ and is more related to fetal growth (Daughaday \& Rotwein 1989). However, recent studies have suggested that both IGF-I and IGF-II may play important roles in embryogenesis (DeChiara et al. 1990, Liu et al. 1993). In some teleosts, IGFs are also produced primarily in the liver although they are found in most extrahepatic tissues as well (Duguay et al. 1992, 1994, 1996, Chen et al. 1994).

The GH dependence of liver IGF-I expression has been observed in a number of teleost species. Injection of bovine GH increased IGF-I mRNA and the serum level of the growth factor in salmonids and seabream (Cao et al. 1989, Shamblott et al. 1995). GH induction of IGF-I expression was also observed in primary hepatocytes of tilapia (Schmid et al. 2000). However, whether IGF-II expression in teleost depends on the presence of $\mathrm{GH}$ is controversial. In seabream, it was reported that IGF-II mRNA was not affected by the injection of human GH (Duguay et al. 1996). On the other hand, IGF-II mRNA was reported to be elevated in rainbow trout liver in vitro and in vivo after administration of bovine GH (Shamblott et al. 1995). In extrahepatic tissues, GH-dependent IGF-I mRNA appearance was not detected in salmon and seabream (Duguay et al. 1994, 1996), and IGF-II mRNA was also not responsive to $\mathrm{GH}$ administration in seabream (Duguay et al. 1996). However, in rainbow trout, the IGF-II level was increased in the pyloric ceca after injection of GH (Shamblott \& Chen 1999). Most studies on IGF expression in bony fish were in fact carried out on the liver, and systematic studies on the GH dependence of IGF expression in other tissues are lacking. The aim of the present study was thus to develop quantitative methods of ascertaining the expression levels of IGF-I and IGF-II in 
common carp tissues using real-time PCR techniques, and to study their basal expression levels in both hepatic and extrahepatic tissues as well as their differential regulation by GH.

The TaqMan method that we employed signals the formation of PCR amplicons by a process involving the nucleolytic degradation of a double-labeled fluorogenic probe that hybridizes to the target template at a site between the forward and reverse primer recognition sequences (Bassler et al. 1995, Livak et al. 1995). The probe has a quencher dye at its $3^{\prime}$ end and a reporter dye at the $5^{\prime}$ end. Fluorescence emission from the reporter is quenched by the quencher dye until nuclease degradation during the extension phase of the PCR separates the two dyes and enables detection of the reporter dye fluorescence (Gibson et al. 1996, Heid et al. 1996). The ABI Prism 7700 Sequence Detection System automates the detection and quantitative measurement of these signals, which are stoichiometrically related to the quantities of amplicons produced, during each cycle of amplification (Heid et al. 1996). In addition to providing substantial reductions in the time and labor requirements for PCR analyses, this technology permits simplified and highly accurate quantification of target sequences in the reactions (Gibson et al. 1996, Heid et al. 1996).

Results of the real-time PCR are analyzed by comparing the threshold cycle $\left(\mathrm{C}_{T}\right)$ values, where $\mathrm{C}_{\mathrm{T}}$ is defined as the threshold cycle number of PCR at which the sample fluorescence signal passes a fixed threshold above the baseline (Johnson et al. 2000). Samples with a high content of the target message would thus show an early increase in fluorescence during the PCR process, resulting in a low $\mathrm{C}_{\mathrm{T}}$ value. On the other hand, samples with a low content of the target message would result in a higher $\mathrm{C}_{\mathrm{T}}$ value. In the present study, an application of this comparative $\mathrm{C}_{\mathrm{T}}$ method was devised to quantify the fold induction of IGF expression after $\mathrm{GH}$ treatment. This comparative $\mathrm{C}_{\mathrm{T}}$ method eliminates the need for standard curves, and employs the formula $\left(2^{-\Delta \Delta \mathrm{C}_{\mathrm{T}}}\right)$ to determine the target message quantities in the test samples relative to the control. Specifically, the method was performed by subtracting the mean of the 18S rRNA (reference sequence) $\mathrm{C}_{\mathrm{T}}$ values from the mean of the IGF-I or IGF-II (target sequences) $\mathrm{C}_{\mathrm{T}}$ values for both the samples and the control in order to obtain $\Delta \mathrm{C}_{\mathrm{T}}$ values. The $\Delta \mathrm{C}_{\mathrm{T}}$ values of the control samples are then subtracted from the $\Delta \mathrm{C}_{\mathrm{T}}$ values of the test samples to obtain the $\Delta \Delta \mathrm{C}_{\mathrm{T}}$ values. The fold induction in the IGF-I or IGF-II level of the GH-treated sample as compared with the control was obtained by substituting into the formula. This method has been successfully applied to the quantitative detection of the expression levels of several growth factors in the same tissue (Chang et al. 2001).

RT-PCR errors in the quantification of mRNA transcripts are easily compounded by any variation in the amount of starting material between samples. This is especially relevant when the samples are obtained from different individuals, resulting in the misinterpretation of the expression profiles of the target genes. A generally accepted method for minimizing these errors and correcting for sample-to-sample variation is to amplify, simultaneously with the target gene, a cellular RNA that serves as an internal reference against which other RNA values can be normalized (Karge et al. 1998). The ideal internal standard should be expressed at a constant level among different tissues of an organism, at all stages of development, and should be unaffected by the experimental treatment. In the present study, $18 \mathrm{~S}$ rRNA was used as the internal control, as the various rRNA transcripts are generated by a distinct polymerase (Paule \& White 2000) and their levels are less likely to vary under conditions that affect the expression of mRNAs (Barbu \& Dautry 1989).

\section{Materials and Methods}

\section{Injection of $G H$ and tissue $R N A$ preparation}

Rapidly growing juvenile common carp (3 to 4 months old) weighing about $30 \mathrm{~g}$ were reared in a circulating water tank kept at $22-25{ }^{\circ} \mathrm{C}$ under natural photoperiod. After 5 days of starvation, the carp were given an i.p. injection of either $10 \mu \mathrm{g}$ recombinant porcine $\mathrm{GH} / \mathrm{g}$ body weight (Bresagen, Thebarton, SA, Australia) or the carrier solution $(10 \mathrm{mM} \mathrm{NaHCO}, \mathrm{pH} 8.0)$ for $6 \mathrm{~h}$. This starvation regimen has been reported to reduce the tissue expression of IGFs and increase the sensitivity of the tissues to GH administration (Duan \& Plisetskaya 1993, Shamblott et al. 1995). Brain, gill, heart, intestine, kidney, liver and muscle were collected from six GH-treated and six control fish. Total RNA was isolated from the fish tissues using Tri-isolation reagent (Roche, Indianapolis, IN, USA). The quality of the RNA was assessed by agarose gel electrophoresis, which showed intact $28 \mathrm{~S}$ and $18 \mathrm{~S}$ rRNA species. All samples were frozen in liquid nitrogen and kept at $-80^{\circ} \mathrm{C}$ until assayed.

\section{First strand cDNA synthesis}

RNA $(5 \mu \mathrm{g})$ was reverse transcribed in a $20 \mu \mathrm{l}$ reaction for $1.5 \mathrm{~h}$ at $37^{\circ} \mathrm{C}$. The reaction mixture consisted of $10 \mathrm{pmol}$

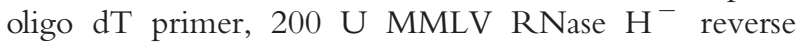
transcriptase in $1 \times$ reverse transcriptase buffer, $10 \mathrm{mM}$ dithiothreitol, $1 \mathrm{mM}$ dNTP and $2 \mathrm{U}$ RNase inhibitor (Invitrogen, Carlsbad, CA, USA). Ten microliters of each cDNA were mixed with $90 \mu \mathrm{l}$ nuclease-free sterile distilled water, and this diluted preparation was used as the template of each TaqMan assay for the three target genes, viz IGF-I, IGF-II and $18 \mathrm{~S}$ rRNA.

\section{Oligonucleotide primers and TaqMan probe design}

The cDNA sequences of IGF-I and IGF-II in common carp have been reported by us previously (Liang et al. 
Table 1 Sequences of PCR primers and specific probes for the detection of IGF-I, IGF-II, and 18S rRNA in common carp by real-time PCR

\begin{tabular}{|c|c|c|c|}
\hline & Primer/probe & Sequence $\left(5^{\prime} \rightarrow 3^{\prime}\right)$ & Amplicon length (bp) \\
\hline $\begin{array}{l}\text { Target gene } \\
\text { IGF-I }\end{array}$ & $\begin{array}{l}\text { Forward primer } \\
\text { Reverse primer } \\
\text { Probe }\end{array}$ & $\begin{array}{l}\text { CGCCTCGAGATGTATTGTGCAC } \\
\text { CTGTATGCCGTTGCGCTCGT } \\
\text { CCGGCAAAACTCCACGATCCG }\end{array}$ & 72 \\
\hline IGF-II & $\begin{array}{l}\text { Forward primer } \\
\text { Reverse primer } \\
\text { Probe }\end{array}$ & $\begin{array}{l}\text { ACCACCACAGGCCTCTCATC } \\
\text { CATCGACTCTGTGCAAAAAGGA } \\
\text { CGCTTCCСAGCAAGCTCCCGCСC }\end{array}$ & 66 \\
\hline $18 \mathrm{~S}$ RNA & $\begin{array}{l}\text { Forward primer } \\
\text { Reverse primer } \\
\text { Probe }\end{array}$ & $\begin{array}{l}\text { AATCCCTGCCCTITGTACACAC } \\
\text { TCCGAGGACCTCACTAAACCA } \\
\text { CGCCCGTCGCTACTACCGATTGGA }\end{array}$ & 66 \\
\hline
\end{tabular}

1996, Tse et al. 2002). Sequence information on the common carp $18 \mathrm{~S}$ rRNA is also available (GenBank accession number U87963 at the National Center for Biotechnology Information database). Gene-specific primers and probes for these three target genes were designed using the ABI Primer Express program (PEApplied Biosystems, Foster City, CA, USA) according to the manufacturer's instructions. This program selects probe and primer sets with optimized melting temperatures, secondary structures, base compositions and amplicon lengths for use with the TaqMan PCR product detection system on the ABI Prism 7700 Sequence Detection System (PE-Applied Biosystems, Foster City, CA, USA). The sequences of the TaqMan probes and primers are shown in Table 1.

The TaqMan probes and primers used in this study were obtained from PE-Applied Biosystems and Invitrogen respectively, with HPLC purification. Each of the TaqMan probes contained a 6-carboxytetramethylrhodamine (TAMRA) group conjugated to its $3^{\prime}$ end and a 6-carboxyfluorescein (FAM) group (for IGF-I and IGF-II) or a VIC group (for 18S rRNA) linked to its $5^{\prime}$ end as the quencher and reporter fluorochromes respectively.

\section{PCR components and cycling conditions}

Reactions were prepared in $0.2 \mathrm{ml}$ thin-walled, optical grade PCR tubes (PE-Applied Biosystems) containing the following components: $12.5 \mu \mathrm{l}$ Platinum Quantitative PCR SuperMix-uracil DNA glycosylase (UDG) (a $2 \times$ concentrated mixture of Platinum Taq DNA polymerase, $\mathrm{Mg}^{2+}$, UDG, dNTPs with UTP and optimized buffer components from Invitrogen); $1 \mu \mathrm{l}$ of a mixture of forward and reverse primers $(5 \mu \mathrm{M}$ each); $0 \cdot 25 \mu \mathrm{l} 10 \mu \mathrm{M}$ TaqMan probe; $0.5 \mu \mathrm{l}$ Rox reference dye (Invitrogen); $0.75 \mu \mathrm{l}$ nuclease-free water; $10 \mu \mathrm{l} \mathrm{cDNA}$ template.

Standard procedures for the operation of the ABI Prism 7700 were followed in this study. This included the use of all default program settings with the exception of the reaction volume which was changed from $50 \mu \mathrm{l}$ to $25 \mu \mathrm{l}$. Thermal cycle conditions consisted of $2 \mathrm{~min}$ at $50^{\circ} \mathrm{C}$, $10 \mathrm{~min}$ at $95^{\circ} \mathrm{C}$, followed by 40 cycles of $15 \mathrm{~s}$ at $95^{\circ} \mathrm{C}$ and $1 \mathrm{~min}$ at $60^{\circ} \mathrm{C} . \mathrm{C}_{\mathrm{T}}$ determinations were performed by the instrument for each reaction using default parameters. Assays for IGF-I, IGF-II and 18S rRNA levels from the same samples were performed in separate reaction tubes.

\section{Relative efficiency of target and reference amplification}

For the $\Delta \Delta \mathrm{C}_{\mathrm{T}}$ calculation to be valid, the efficiency of the target amplification and the efficiency of the reference amplification must be approximately the same. A sensitive method to assess whether the two amplicons (IGF-I/18S rRNA, IGF-II/18S rRNA) possess the same amplification efficiency is to look at how changes in relative $\mathrm{C}_{\mathrm{T}}$ values $\left(\Delta \mathrm{C}_{\mathrm{T}}\right)$ vary with template dilution. The $\Delta \mathrm{C}_{\mathrm{T}}$ was plotted against the logarithm of the dilution factor, and the slope was determined.

\section{Results}

Determination of the linear range of PCR amplification

Initial studies were performed on optimizing the oligonucleotide primer and TaqMan probe concentrations using liver first strand cDNA as template. The relationship between the $C_{T}$ value and the logarithm of the dilution factor of template cDNA was evaluated under the optimized conditions of amplifying the target genes (IGF-I and IGF-II) and the normalization gene (18S rRNA) and were shown to be linear with a correlation coefficient larger than 0.99 (Fig. 1).

\section{Validation of the real-time quantitative PCR}

Before the comparative $\mathrm{C}_{\mathrm{T}}$ method for quantitation was adopted, a validation experiment was performed to demonstrate that the inherent amplification efficiencies of the target and reference sequences were approximately equal 
(a)

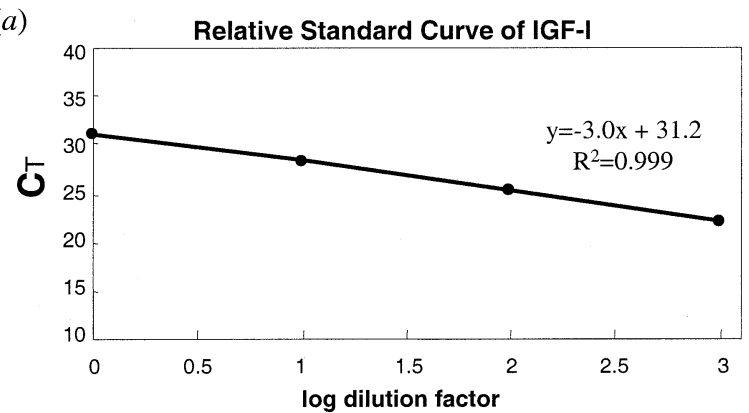

(b)

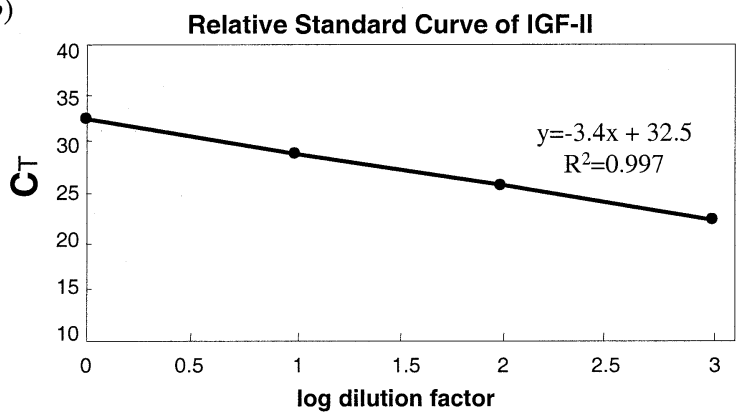

(c)

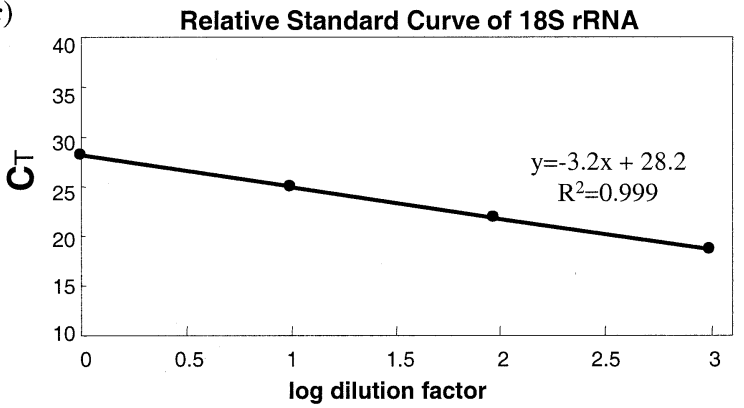

Figure 1 Linear relationship between $\mathrm{C}_{\mathrm{T}}$ and logarithm of the dilution factor of liver first strand cDNA. The relative standard curves were generated using (a) the IGF-I specific primers and probe, $(b)$ the IGF-II specific primers and probe, and (c) the $18 \mathrm{~S}$ rRNA specific primers and probe. The average $C_{T}$ values are plotted against the logarithm of the dilution factor of the cDNA template.

(User Bulletin No. 2 of the ABI Prism Model 7700 Sequence Detection System) through a comparison of the $\mathrm{C}_{\mathrm{T}}$ results obtained from the corresponding serial dilutions of the target and reference templates. The absence of significant changes in $\Delta \mathrm{C}_{\mathrm{T}}$ with decreasing concentrations of the templates is an indicator that the amplification efficiencies are the same, i.e. the absolute value of the slope of the $\Delta \mathrm{C}_{\mathrm{T}}$ versus log dilution factor plot should be less than $0 \cdot 1$. Once this is established, the $\Delta \Delta \mathrm{C}_{\mathrm{T}}$ calculation for the relative quantitation of the target can be used without running standard curves on the same plate (Johnson et al. 2000).
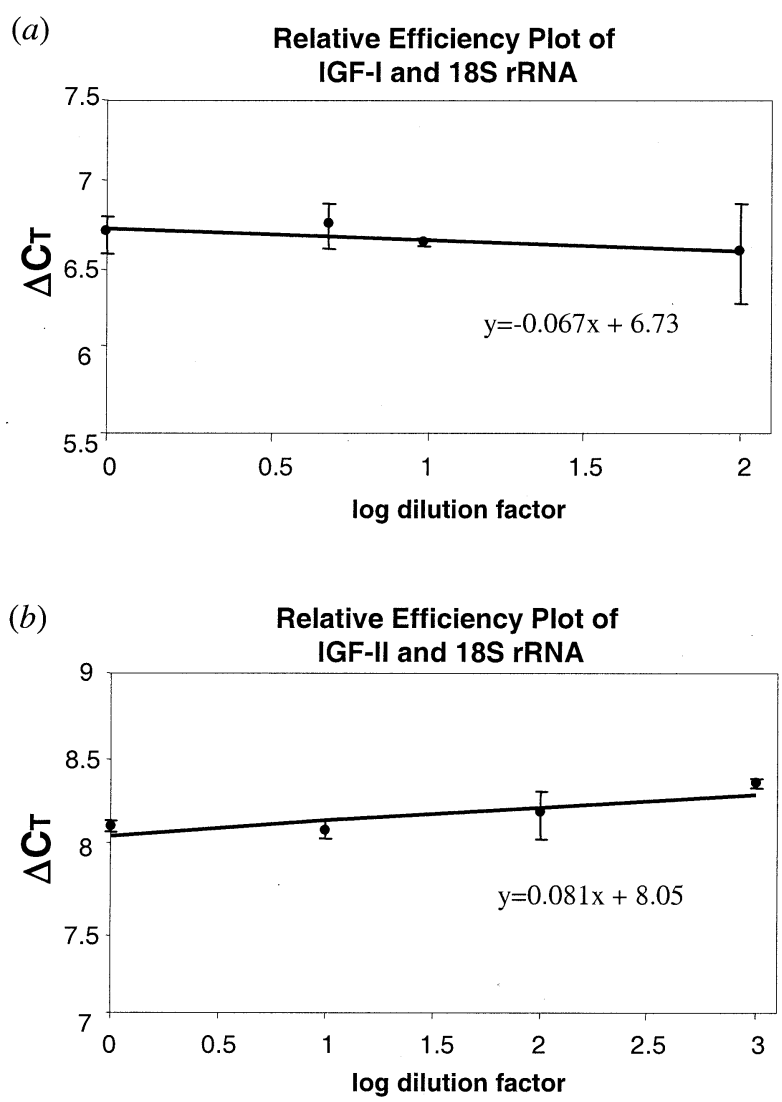

Figure 2 Validation experiment for the comparative $C_{T}$ method: plot of $\Delta C_{T}$ versus log dilution factor. Serial dilutions of liver first strand CDNA were used to perform the real-time PCR. The $\Delta C_{T}$ between IGF-I and 18S rRNA (a) and between IGF-II and 18S rRNA $(b)$ were plotted against the log dilution factor respectively.

Serial dilutions of liver first strand cDNA were used to perform the real-time PCR. The $\Delta \mathrm{C}_{\mathrm{T}}$ between IGF-I/ $18 \mathrm{~S}$ rRNA and IGF-II/18S rRNA were plotted against log dilution factor respectively. As can be observed in Fig. 2 , the slope of the $\Delta \mathrm{C}_{\mathrm{T}}$ versus $\log$ dilution factor plot for IGF-I/18S rRNA was $0 \cdot 067$, and the slope of the $\Delta \mathrm{C}_{\mathrm{T}}$ versus $\log$ dilution factor plot for IGF-II/18S rRNA was $0 \cdot 081$, both of them being less than the recommended value of $0 \cdot 1$. The conditions for amplifying IGF-I/18S rRNA and IGF-II/18S rRNA were therefore reliable in adopting the comparative $\mathrm{C}_{\mathrm{T}}$ method.

\section{Differential expression of IGF-I and IGF-II in common carp} tissues

The established real-time PCR method was used to determine the mRNA levels of IGF-I and IGF-II in the brain, gill, heart, intestine, kidney, liver and muscle of rapidly growing juvenile (3- to 4-month-old) fish. The IGF mRNA levels determined are summarized in Fig. 3. IGF-I and IGF-II were expressed in all of the tissues 
Tissue distribution of IGF-I and IGF-II in Common Carp

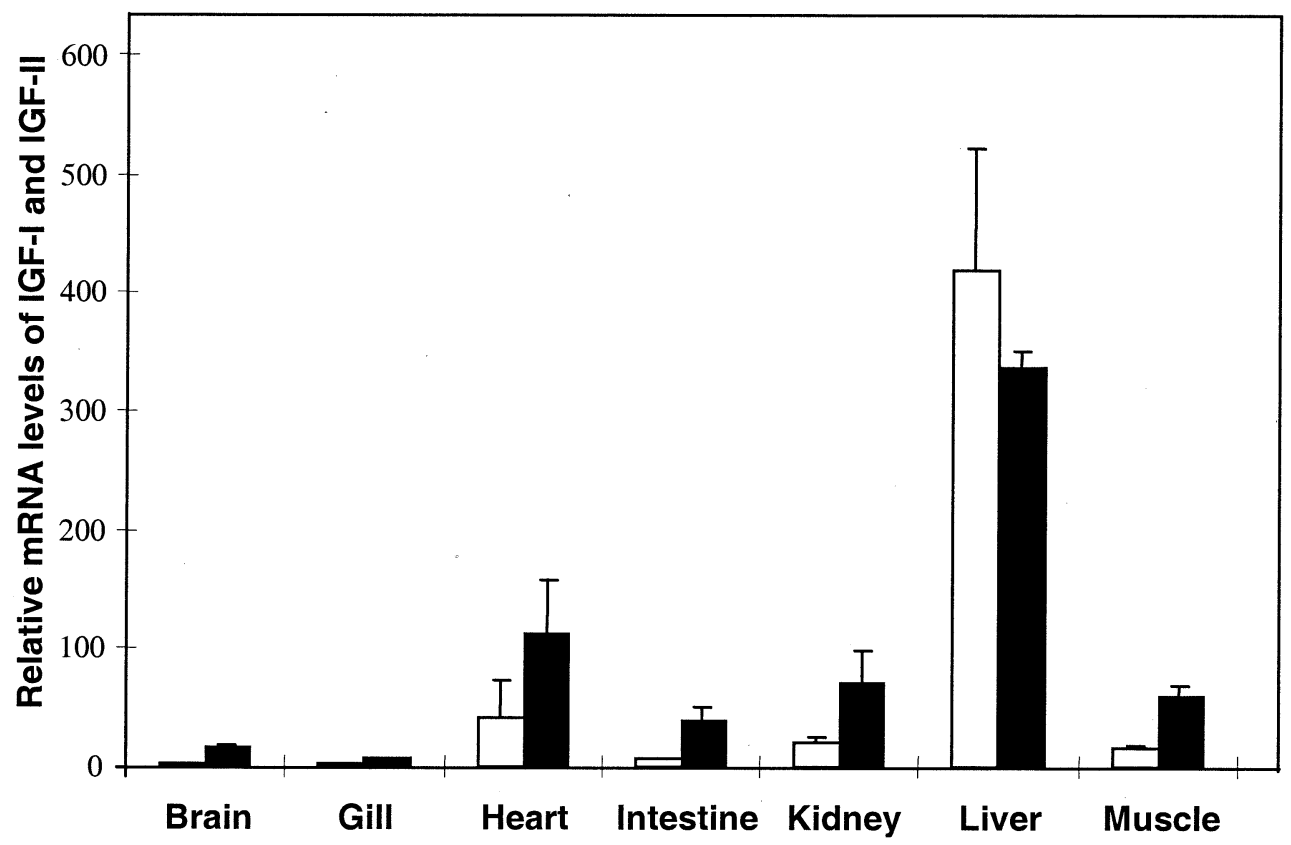

Figure 3 Tissue distribution of IGF-I and IGF-II mRNA in juvenile common carp. The IGF mRNA levels, as measured by real-time PCR, were normalized with $18 \mathrm{~S}$ rRNA. The open bars represent the mRNA levels of IGF-I. The solid bars represent the mRNA levels of IGF-II. Results are expressed in arbitrary units. Value are means \pm S.D. $(n=4)$. Differences between IGF-I and IGF-II levels are significant $(P<0 \cdot 05$ by Student's $t$-test $)$ in all tissues except liver and gill.

examined, with liver being the site of the highest expression for both growth factors. While the IGF-I and IGF-II levels in the liver and the gill were not significantly different from each other, the IGF-II level was higher than the IGF-I level in most of the extrahepatic tissues.

\section{Differential regulation of IGF-I and IGF-II expression by GH in common carp}

The effect of GH administration on IGF expression in common carp was examined by injecting juvenile fish with recombinant porcine GH. IGF mRNA levels were determined in the common carp tissues by the established real-time PCR methods (Fig. 4).

The liver showed the most dramatic response to $\mathrm{GH}$ treatment. A dose of $10 \mu \mathrm{g} / \mathrm{g}$ body weight of porcine $\mathrm{GH}$ produced a 6-fold increase in IGF-I mRNA level and a $2 \cdot 7$-fold increase in IGF-II mRNA level, as compared with the control group which received the carrier solution $(10 \mathrm{mM} \mathrm{NaHCO} 3, \mathrm{pH} 8 \cdot 0)$. In gill, both IGF-I and IGF-II levels were increased by the GH treatment, giving a $2 \cdot 7$-fold and $2 \cdot 5$-fold increase respectively. In intestine, the IGF-I and IGF-II mRNA levels were also increased by $\mathrm{GH}$ to give a 3 -fold and 2-fold increase respectively. Interestingly, the IGF-II levels were increased by GH in the kidney and muscle, giving a 1.7-fold and 3.4-fold increase respectively, but the IGF-I levels in these two tissues showed no significant increase under these situations. Conversely, the brain IGF-I level was increased significantly by approximately $40 \%$ by the GH treatment, but the IGF-II level was not affected. In the heart, however, neither IGF-I nor IGF-II levels responded to the $\mathrm{GH}$ treatment at all.

\section{Discussion}

Over the past decade, several techniques have been utilized to evaluate gene expression levels, including Northern blot analysis, ribonuclease protection assay and quantitative RT-PCR. Although widely cited in the literature, Northern blot analysis and ribonuclease protection assay both require relatively large amounts of RNA which may be limiting when analysing small tissue samples or blood preparations. In addition, these methods are only semiquantitative in nature and are too laborious to be performed on a routine basis. Competitive RT-PCR is, in fact, one of the most sensitive and reliable methods for mRNA quantitation (Zimmermann \& Mannhalter 1996). However, it requires validation studies to ensure that the amplification efficiencies of the target and the competitor are identical, and the post-PCR quantitation work is 

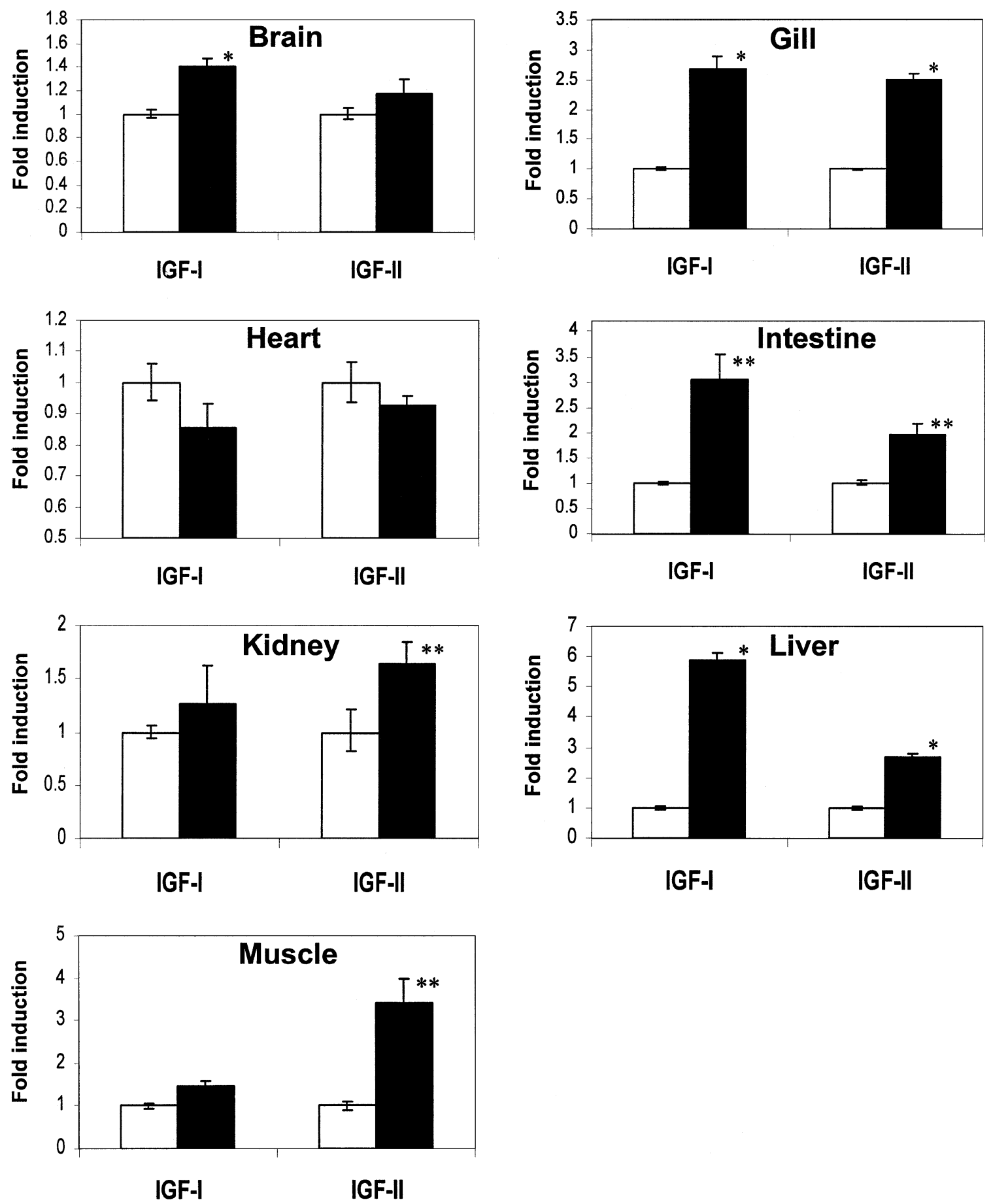

Figure $4 \mathrm{GH}$-dependent induction of IGF-I and IGF-II mRNA in common carp tissues. The levels of IGF mRNAs were determined by real-time PCR and were normalized by $18 \mathrm{~S}$ rRNA. The open bars represent the levels in control fish, and the solid bars represent the levels in $\mathrm{GH}(10 \mu \mathrm{g} / \mathrm{g}$ body weight)-treated fish. Results are expressed as fold inductions compared with each control group. Values are means \pm S.D. $(n=6) .{ }^{*} P<0 \cdot 01,{ }^{*} P<0 \cdot 05$ by Student's $t$-test.

rather labor intensive. Recent development in realtime quantitative PCR appears to have overcome these limitations.
Real-time quantitative PCR is based on the $5^{\prime} \rightarrow 3^{\prime}$ nuclease activity of the Taq DNA polymerase (Holland et al. 1991). Signal detection depends on the fluorescent 
dyes FAM/VIC and TAMRA, which are linked to the $5^{\prime}$ and $3^{\prime}$ ends of the oligonucleotide respectively. The FAM and VIC work as reporters while TAMRA is a quencher. The $3^{\prime}$ end of this oligonucleotide is blocked by phosphorylation, preventing elongation by the Taq DNA polymerase. During PCR amplification, the enzyme displaces the probe from the template, cleaves it by its $5^{\prime} \rightarrow 3^{\prime}$ nuclease activity and thus separates the reporter dye from the quencher dye. The fluorescence emitted is directly proportional to the number of template molecules in the reaction. Each cycle further increases this signal (Holland et al. 1991), thereby permitting careful monitoring of the reaction kinetics. Quantification relies on the detection of the $\mathrm{C}_{\mathrm{T}}$, which is defined as the fractional cycle number at which the fluorescence passes the fixed threshold (Kruse et al. 1997).

Data analysis using the comparative $\mathrm{C}_{\mathrm{T}}$ method has advantages over the relative or absolute standard curve method since it does not require the construction of a standard curve. However, a validation experiment must be performed to demonstrate that the amplification efficiencies of the target gene and the normalization gene are approximately equal. This can be achieved by plotting the $\Delta \mathrm{C}_{\mathrm{T}}$ against the logarithm of the dilution factor of the first strand cDNA. Linear regression analyses of the lines generated for IGF-I/18S rRNA and IGF-II/18S rRNA are shown in Fig. 2 with the equations describing the two linear lines respectively. If the slope of the line is zero, then the efficiencies of the IGF and 18S rRNA amplifications are approximately equal. The absolute values of the slopes for our plots for IGF-I/18S rRNA and IGF-II/18S rRNA were 0.067 and 0.081 respectively, which were lower than the recommended value of less than $0 \cdot 1$ (User Bulletin No.2 of the ABI Prism Model 7700 Sequence Detection System). Therefore, the $\Delta \Delta \mathrm{C}_{\mathrm{T}}$ calculation for the relative quantitation of the targets can be used without running standard curves on the same plate.

To date, most studies on fish IGFs have been carried out on salmonid species. In addition, not much is known in fish about the GH dependence of IGF-I and IGF-II expression in extrahepatic tissues. Since the expression levels of IGFs are relatively low in extrahepatic tissues, using the highly sensitive method of real-time PCR enables these low levels to be studied accurately, particularly in situations where very small amounts of the tissues are available. The present study analyzes the differential expression and regulation of IGF-I and IGF-II in common carp tissues by real-time PCR.

The basal expression pattern of IGFs in common carp, as shown in Fig. 3, is similar to that of the rainbow trout (Greene \& Chen 1997). Both IGF-I and IGF-II are expressed in all the tissues examined. Liver is the major site of IGF production, and the hepatic levels of IGF-I and IGF-II are at least two to three orders of magnitude higher than that of other tissues. While the IGF-I and IGF-II levels in the common carp liver and gill are not signifi- cantly different from each other, the IGF-II levels are much higher than that of IGF-I in most extrahepatic tissues. These results are different from the situation found in mammals (Lund et al. 1986, Rotwein et al. 1987, Stylianopoulou et al. 1988, Holthuizen et al. 1993). While the expression pattern of IGF-I in mammals is similar to that of teleosts, the expression pattern of IGF-II is very different. In mammals, IGF-II mRNA is readily detected in many tissues of the fetus but the level decreases rapidly during postnatal development. This is in contrast to teleostean tissues which still express a substantial amount of IGF-II later in life at a level which is in fact higher than that of IGF-I in most extrahepatic tissues (Fig. 3). These results suggest that, in addition to IGF-I, IGF-II may also play an important role in the growth and development of common carp, not only in the early embryonic stage (Tse et al. 2002), but also during later life. This is also substantiated by the fact that both IGF-I and IGF-II are stimulated to express by GH in some common carp tissues (Fig. 4).

The growth-promoting effects of GH are known to be mediated to a large extent by IGF-I. Since this concept was first formulated almost 50 years ago (Salmon \& Daughaday 1957) it has been shown that GH stimulates specific cells to produce IGF-I which, in turn, acts as a mitogenic agent on cells of many different lineages. It has now become clear that transcription of the IGF-I gene, e.g. in liver in vivo (Bichell et al. 1992) and in primary hepatocyte in vitro (Norstedt \& Moller 1987), is strongly enhanced by the action of GH. However, the GH dependence of IGF-II expression is less established, particularly in fish where conflicting information has been reported.

Our data clearly demonstrate that the liver is the major organ of expression of both IGF-I and IGF-II in common carp. In addition, the levels of both growth factors in the common carp liver were significantly increased by GH administration, where there was a large (6-fold) increase in IGF-I expression and a substantial (2.7-fold) increase in IGF-II expression. Thus, at a time when the common carp is rapidly growing, the liver is very responsive to $\mathrm{GH}$ stimulation to express both growth factors which are therefore implicated as playing important roles in the growth and development of the fish.

In rainbow trout, the IGF-II level in the pyloric ceca was elevated by about 2- to 4-fold upon GH stimulation. However, the level of IGF-I mRNA was undetectable since its expression level was too low in this tissue (Shamblott et al. 1995). In common carp, both the IGF-I and IGF-II levels in the intestine were significantly increased by 3 -fold and 2-fold respectively upon administration of GH (Fig. 4). GH-stimulated enhancement of amino acid uptake has been demonstrated in teleost species including coho salmon and striped bass (Collie \& Stevens 1985). The GH induction of IGF-I and IGF-II in the common carp intestine suggests a role of both growth factors in mediating the actions of $\mathrm{GH}$ in enhancing intestinal absorption in fish. 
Interestingly, the muscle IGF-II level in common carp was elevated by 3.4-fold upon GH treatment, while the IGF-I showed little and insignificant response to the same treatment. In fact, the result of the muscle IGF-I response to $\mathrm{GH}$ in common carp is the same as in seabream and salmon (Duguay et al. 1994, 1996). However, the result of the muscle IGF-II response to GH in common carp was very different from seabream in which muscle IGF-II did not respond to GH stimulation at all. These results suggest a more significant role of IGF-II in the GHstimulated somatic growth in carp than in other teleostean species.

In addition to stimulation of growth, $\mathrm{GH}$ is believed to play a major role in osmoregulation during parr-to-smolt transformation in salmon. The circulating $\mathrm{GH}$ increases during the transfer of salmon from fresh water to seawater, whether in seawater challenge experiments or during natural migration to seawater (Sweeting et al. 1985, Young et al. 1989). GH can also reduce the plasma sodium concentration (Bolton et al. 1987, Collie et al. 1989), and increase gill $\mathrm{Na}^{+} / \mathrm{K}^{+}$-ATPase activity in salmonids (Bjornsson et al. 1987, Richman \& Zaugg 1987). The osmoregulatory actions of IGF-I have also been tested directly (McCormick et al. 1991) by injection of GH, IGF-I and insulin into rainbow trout followed by measurement of the plasma osmolarity in response to seawater challenge. Recombinant bovine IGF-I decreased plasma osmolarity and sodium ion concentrations in a dosedependent manner, and ovine GH could also decrease plasma osmolarity and sodium ion concentrations, whereas native salmon insulin had no effect at all. These data suggest that the osmoregulatory actions of $\mathrm{GH}$ in rainbow trout might be mediated by IGF-I. In the present study, the finding of the GH induction of gill IGF-I and IGF-II and of kidney IGF-II in common carp indicates that the osmoregulatory action of GH is probably not only limited to migratory salmonids but also to carp which dwell only in fresh water. In addition, it seems that this action of GH is mediated not only by IGF-I but by IGF-II as well.

A low but definitive expression of both IGF-I and IGF-II is found in the common carp heart (Fig. 3). While the functional significance of these growth factors in the cardiac system of the fish is not known, these expressions appear to be constitutive in nature because they were unresponsive to GH stimulation (Fig. 4). The same applies to the IGF-II level in the brain. However, a small but consistent increase (about 40\%) in IGF-I expression was seen in the common carp brain upon $\mathrm{GH}$ administration (Fig. 4). The GH receptor is known to be expressed significantly in the brain of goldfish (a carp) (Lee et al. 2001) and is implicated in the negative feedback of GH secretion in this species (Marchant et al. 1989). The stimulation of IGF-I expression by $\mathrm{GH}$ in the brain indicates that IGF-I might be mediating the central neural function of $\mathrm{GH}$ in common carp.
In conclusion, we have developed highly sensitive methods for assessing IGF-I and IGF-II mRNA levels in common carp tissues by real-time PCR. The methods were applied to the quantitative analysis of the mRNA levels of the two growth factors in different tissues of the fish. Such studies are vital for understanding the differential regulation of expression of these growth factors under different hormonal and physiological manipulations of the fish and would help us to delineate the biological significance of these growth factors in common carp.

\section{Acknowledgements}

We are grateful to the Au Tau Fisheries Office of the Agriculture, Fisheries and Conservation Department of the Hong Kong SAR Government for the provision of carp for the experiments. We are also grateful to the Chinese University of Hong Kong for the award of Direct and Strategic Grants, and to United College for financial support through the Lee Hysan \& Endowment Research Funds and the Student Campus Work Scheme.

\section{References}

Barbu V \& Dautry F 1989 Northern blot normalization with a 28S rRNA oligonucleotide probe. Nucleic Acids Research 177115.

Bassler HA, Flood SJ, Livak KJ, Marmaro J, Knorr R \& Batt CA 1995 Use of a fluorogenic probe in a PCR-based assay for the detection of Listeria monocytogenes. Applied and Environmental Microbiology 61 3724-3728.

Bichell DP, Kikuchi K \& Rotwein P 1992 Growth hormone rapidly activates insulin-like growth factor I gene transcription in vivo. Molecular Endocrinology 6 1899-1908.

Bjornsson BT, Yamauchi K, Nishioka RS, Deftos LJ \& Bern HA 1987 Effects of hypophysectomy and subsequent hormonal replacement therapy on hormonal and osmoregulatory status of coho salmon, Oncorhynchus kisutch. General and Comparative Endocrinology 68 421-430.

Bolton JP, Collie NL, Kawauchi H \& Hirano T 1987 Osmoregulatory actions of growth hormone in rainbow trout (Salmo gairdneri). Journal of Endocrinology 112 63-68.

Cao QP, Duguay SJ, Plisetskaya E, Steiner DF \& Chan SJ 1989 Nucleotide sequence and growth hormone-regulated expression of salmon insulin-like growth factor I mRNA. Molecular Endocrinology 3 2005-2010.

Chang JT, Chen IH, Liao CT, Wang HM, Hsu YM, Hung KF, Lin CJ, Hsieh LL \& Cheng AJ 2001 A reverse transcription comparative real-time PCR method for quantitative detection of angiogenic growth factors in head and neck cancer patients. Clinical Biochemistry 35 591-596.

Chen TT, Shamblott MJ, Lin CM, Tang YL, Chan KM, Cheng CM, Yang BY \& Marsh A 1994 Structure and evolution of fish growth hormone and insulin-like growth factor genes. In Fish physiology, vol 13, pp 179-224. Eds NM Sherwood \& CL Hew. San Diego: Academic Press Inc.

Collie NL \& Stevens JJ 1985 Hormonal effects on L-proline transport in coho salmon (Oncorhynchus kisutch) intestine. General and Comparative Endocrinology 59 399-409.

Collie NL, Bolton JP, Kawauchi H \& Hirano T 1989 Survival of salmonids in seawater and the time-frame of growth hormone action. Fish Physiology and Biochemistry 7 315-321. 
Daughaday WH \& Rotwein P 1989 Insulin-like growth factors I and II. Peptide, messenger ribonucleic acid and gene structures, serum, and tissue concentrations. Endocrine Reviews 10 68-91.

DeChiara TM, Efstratiadis A \& Robertson EJ 1990 A growthdeficiency phenotype in heterozygous mice carrying an insulin-like growth factor II gene disrupted by targeting. Nature 345 78-80.

Duan C \& Plisetskaya EM 1993 Nutritional regulation of insulin-like growth factor-I mRNA expression in salmon tissues. Journal of Endocrinology 139 243-252.

Duguay SJ, Park LK, Samadpour M \& Dickhoff WW 1992 Nucleotide sequence and tissue distribution of three insulin-like growth factor I prohormones in salmon. Molecular Endocrinology 6 1202-1210.

Duguay SJ, Swanson P \& Dickhoff WW 1994 Differential expression and hormonal regulation of alternatively spliced IGF-I mRNA transcripts in salmon. Journal of Molecular Endocrinology 12 25-37.

Duguay SJ, Lai-Zhang J, Steiner DF, Funkenstein B \& Chan SJ 1996 Developmental and tissue-regulated expression of IGF-I and IGF-II mRNAs in Sparus aurata. Journal of Molecular Endocrinology 16 123-132.

Froesch ER, Schmid C, Schwander J \& Zapf J 1985 Actions of insulin-like growth factors. Annual Review of Physiology 47 443-467.

Gibson UE, Heid CA \& Williams PM 1996 A novel method for real time quantitative RT-PCR. Genome Research 6 995-1001.

Greene MW \& Chen TT 1997 Temporal expression pattern of insulin-like growth factor mRNA during embryonic development in a teleost, rainbow trout (Onchorynchus mykiss). Molecular Marine Biology and Biotechnology 6 144-151.

Heid CA, Stevens J, Livak KJ \& Williams PM 1996 Real time quantitative PCR. Genome Research 6 986-994.

Holland PM, Abramson RD, Watson R \& Gelfand DH 1991 Detection of specific polymerase chain reaction product by utilizing the $5^{\prime} \rightarrow 3^{\prime}$ exonuclease activity of Thermus aquaticus DNA polymerase. PNAS 88 7276-7280.

Holthuizen PE, Cleutjens CB, Veenstra GJ, van der Lee FM, Koonen-Reemst AM \& Sussenbach JS 1993 Differential expression of the human, mouse and rat IGF-II genes. Regulatory Peptides $\mathbf{4 8}$ 77-89.

Johnson MR, Wang K, Smith JB, Heslin MJ \& Diasio RB 2000 Quantitation of dihydropyrimidine dehydrogenase expression by real-time reverse transcription polymerase chain reaction. Analytical Biochemistry 278 175-184.

Karge WH III, Schaefer EJ \& Ordovas JM 1998 Quantification of mRNA by polymerase chain reaction (PCR) using an internal standard and a nonradioactive detection method. Methods in Molecular Biology 110 43-61.

Kruse N, Pette M, Toyka K \& Rieckmann P 1997 Quantification of cytokine mRNA expression by RT PCR in samples of previously frozen blood. Journal of Immunological Methods 210 195-203.

Lee LTO, Nong G, Chan YH, Tse DLY \& Cheng CHK 2001 Molecular cloning of a teleost growth hormone receptor and its functional interaction with human growth hormone. Gene $\mathbf{2 7 0}$ $121-129$.

Liang YH, Cheng CHK \& Chan KM 1996 Insulin-like growth factor IEa2 is the predominantly expressed form of IGF in common carp (Cyprinus carpio). Molecular Marine Biology and Biotechnology $\mathbf{5}$ 145-152.

Liu JP, Baker J, Perkins AS, Robertson EJ \& Efstratiadis A 1993 Mice carrying null mutations of the genes encoding insulin-like growth factor I (Igf-1) and type 1 IGF receptor (Igf1r). Cell 75 59-72.

Livak KJ, Flood SJ, Marmaro J, Giusti W \& Deetz K 1995 Oligonucleotides with fluorescent dyes at opposite ends provide a quenched probe system useful for detecting PCR product and nucleic acid hybridization. PCR: Methods and Applications 4 357-362.
Lowe MW 1991 Biological actions of the insulin-like growth factor. In Insulin-like Growth Factors: Molecular and Cellular Aspects, pp 49-86. Boca Raton, FL: CRC Press.

Lund PK, Moats-Staats BM, Hynes MA, Simmons JG, Jansen M, D'Ercole AJ \& Van Wyk JJ 1986 Somatomedin-C/insulin-like growth factor-I and insulin-like growth factor-II mRNAs in rat fetal and adult tissues. Journal of Biological Chemistry 261 14539-14544.

McCormick SD, Sakamoto T, Hasegawa S \& Hirano T 1991 Osmoregulatory actions of insulin-like growth factor-I in rainbow trout (Oncorhynchus mykiss). Journal of Endocrinology 130 87-92.

Marchant TA, Dulka JG \& Peter RE 1989 Relationship between serum growth hormone levels and the brain and pituitary content of immunoreactive somatostatin in the goldfish, Carassius auratus L. General and Comparative Endocrinology 73 458-468.

Norstedt G \& Moller C 1987 Growth hormone induction of insulin-like growth factor I messenger RNA in primary cultures of rat liver cells. Journal of Endocrinology 115 135-139.

de Pablo F, Scott LA \& Roth J 1990 Insulin and insulin-like growth factor I in early development: peptides, receptors and biological events. Endocrine Reviews 11 558-577.

Paule MR \& White RJ 2000 Survey and summary: transcription by RNA polymerases I and III. Nucleic Acids Research 28 1283-1298.

Richman NH III \& Zaugg WS 1987 Effects of cortisol and growth hormone on osmoregulation in pre- and desmoltified coho salmon (Oncorhynchus kisutch). General and Comparative Endocrinology 65 189-198.

Rotwein P, Pollock KM, Watson M \& Milbrandt JD 1987 Insulinlike growth factor gene expression during rat embryonic development. Endocrinology 121 2141-2144.

Salmon WD \& Daughaday WH 1957 A hormonally controlled serum factor which stimulates sulfate incorporation by cartilage in vitro. Journal of Laboratory and Clinical Medicine 49 825-836.

Schmid AC, Reinecke M \& Kloas W 2000 Primary cultured hepatocytes of the bony fish, Oreochromis mossambicus, the tilapia: a valid tool for physiological studies on IGF-I expression in liver. Journal of Endocrinology 166 265-273.

Shamblott MJ \& Chen TT 1999 Presence of GH-dependent IGF-II mRNA in the diffuse pancreatic tissue of a teleost. Comparative Biochemistry and Physiology Part B 122 287-292.

Shamblott MJ, Cheng CM, Bolt D \& Chen TT 1995 Appearance of insulin-like growth factor mRNA in the liver and pyloric ceca of a teleost in response to exogenous growth hormone. PNAS 92 6943-6946.

Stylianopoulou F, Efstratiadis A, Herbert J \& Pintar J 1988 Pattern of the insulin-like growth factor II gene expression during rat embryogenesis. Development 103 497-506.

Sweeting RM, Wagner GF \& McKeown BA 1985 Changes in plasma glucose, amino acid nitrogen and growth hormone during smoltification and seawater adaptation in coho salmon, Oncorhynchous kisutch. Aquaculture 45 185-197.

Tse MCL, Vong QP, Cheng CHK \& Chan KM 2002 PCR-cloning and gene expression studies in common carp (Cyprinus carpio) insulin-like growth factor-II. Biochimica et Biophysica Acta 1575 63-74.

Young G, Bjornsson BT, Prunet P, Lin RJ \& Bern HA 1989 Smoltification and seawater adaptation in coho salmon (Oncorhynchus kisutch): plasma prolactin, growth hormone, thyroid hormones, and cortisol. General and Comparative Endocrinology 74 335-345.

Zimmermann K \& Mannhalter JW 1996 Technical aspects of quantitative competitive PCR. Biotechniques 21 268-272, 274-279.

Received 31 March 2003

Accepted 10 June 2003 